with the syndrome (13/43) had had similar symptoms in their previous pregnancy.

Symptoms were considered mild if they had lasted from a few seconds to 15 minutes and occurred once a week for at least four weeks ( 44 of the 97 women with the syndrome); moderate if they lasted 15-30 minutes and occurred up to three times a week with occasional disturbance of sleep (46); and severe if they lasted more than 30 minutes and occurred at least three times a week with frequent disturbance of sleep (seven). In 56 patients the symptoms were exacerbated by a tiring day and in 14 by a change in the ambient temperature. Care was taken to exclude patients who were just tired or complained of cramps. Patients with and without the syndrome were similar in respect of distributions of age, parity, social class, smoking habit, presence or absence of varicose veins and rheumatoid arthritis, haemoglobin concentration $(<105 \mathrm{~g} / \mathrm{l})$, and iron folate supplementation.

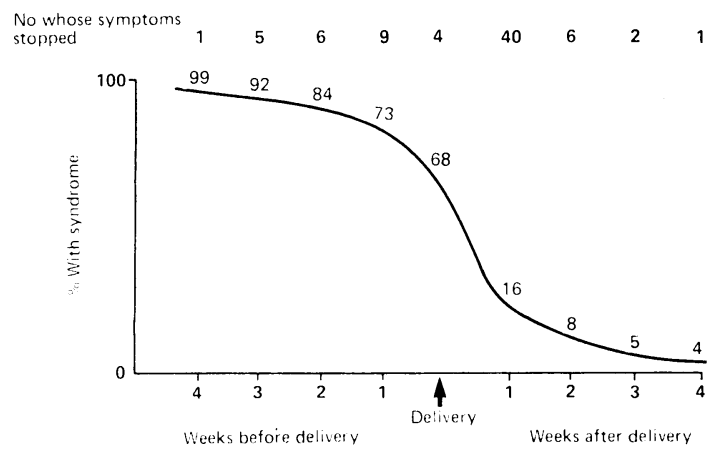

Reduction in number of women with restless leg syndrome before and after delivery who were followed up $(n=77)$

The figure shows the reduction in the number of patients with the syndrome from four weeks before delivery to four weeks after. In the four weeks after delivery the symptoms stopped in all but three women. Half of the patients noticed some improvement in their symptoms in the four weeks before delivery, often related to giving up work or compulsory bed rest. Twenty six patients with the syndrome mentioned their symptoms to their general practitioner; none was given the correct explanation.

\section{Comment}

The prevalence of the restless leg syndrome in any group depends on the patient selected for study and whether symptoms are deliberately sought or spontaneously volunteered. Though our inquiry found that 97 of 500 pregnant women (19\%) had the syndrome, only seven had severe symptoms. Many of those with mild or moderate symptoms were identified only after careful questioning.

By 10 days after delivery only six women who had developed the syndrome during pregnancy still complained of symptoms. Though the aetiology of the condition is poorly understood, the reduction in the prevalence of symptoms from four weeks before delivery to the period soon after may have coincided with a voluntary or enforced period of reduced activity; a tiring day was the most common factor associated with the development of symptoms. Gorman et al also suggested that symptoms occur particularly in patients suffering from anxiety and tension and in normal people during periods of stress. ${ }^{4}$

We were surprised that though $27 \%$ of the patients had told their general practitioner about their symptoms, none had been provided with a satisfactory explanation. The syndrome, especially in pregnancy, is not well known by doctors. Suggesting a reduction in activity to reduce symptoms and reassuring patients that they have a common condition that will almost certainly disappear after delivery should help to allay their worries.

1 Ekbom KA. Restless legs. Acta Med Scand [Suppl] 1945;158:1-123

2 Gibb WRG, Lees AJ. The restless legs syndrome. Postgrad Med $\mathcal{f}$ 1986;62: 329-33.

3 Clough C. Restless legs syndrome. Br Med f 1987;294:262-3.

Gorman CA, Dyck PJ, Pearson JS. Symptoms of restless legs. Arch Intern Med 1965;115:155-60.

(Accepted 14 fuly 1988)

\title{
Heterosexual transmission of HIV by haemophiliacs
}

\author{
Marchina E van der Ende, Philip Rothbarth, \\ Jeanne Stibbe
}

\section{Departments of}

Haematology and Virology, University Hospital Dijkzigt, 3015 GD Rotterdam, The Netherlands Marchina E van der Ende, MD, consultant physician Philip Rothbarth, MD, consultant virologist Jeanne Stibbe, MD, consultant haematologist

Correspondence to: $\mathrm{Dr} J$ Stibbe, Department of Haematology.
Important information on the epidemiology of heterosexual transmission of human immunodeficiency virus (HIV) in the West is lacking, which limits the prediction of future trends. ${ }^{2}$ Haemophiliacs may be regarded as representative of the general population with respect to sexual behaviour and additional risk factors. Haemophiliacs who are positive for HIV antibody and their regular heterosexual partners may therefore serve as a model for transmission of HIV from men to women, from which information can be obtained about the risk of discrete sexual contacts, different sexual practices, the protective effect of barrier methods of contraception, and the chance of transmission.

We report a three year follow up study of 13 haemophiliacs positive for HIV antibody and their spouses.

Patients, methods, and results

In June 1984, 35 patients with haemophilia and their spouses entered a study. We interviewed patients and their partners every three months. Blood samples obtained every three months were screened for cell counts; liver enzyme activity; antibodies to cytomegalovirus, Epstein-Barr virus, and HIV (confirmed by immunoblotting); and HIV antigen. Every six months subsets of $\mathrm{T}$ lymphocytes were counted and lymphocyte stimulation tests performed. Thirteen haemophiliacs were positive for HIV antibody, and the date when they had become positive was established retrospectively for stored serum. In each patient the disease was staged according to the Walter Reed classification (though lymphocyte stimulation tests were used instead of delayed hypersensitivity skin tests): stage $\mathrm{I}=$ no prolonged generalised lymphadenopathy, $>400$ OKT4+ cells; II=lymphadenopathy, $>400$ OKT $4+$ cells; III = lymphadenopathy present or absent, $<400$ OKT4+ cells; IV=depressed results of lymphocyte stimulation tests; $\mathrm{V}=$ opportunistic infections.

None of the patients' partners were positive for HIV antibody at any time during follow up. Patients and partners denied having had homosexual contacts or sexually transmitted diseases or other genitourinary disorders and did not take intravenous drugs.

All couples practised vaginal intercourse. Four partners (cases 4, 5, 12,13) had orogenital contact; two couples (cases 5,10 ) had vaginal intercourse during menstruation; none practised anal intercourse. One patient (case 12) had used condoms before becoming 


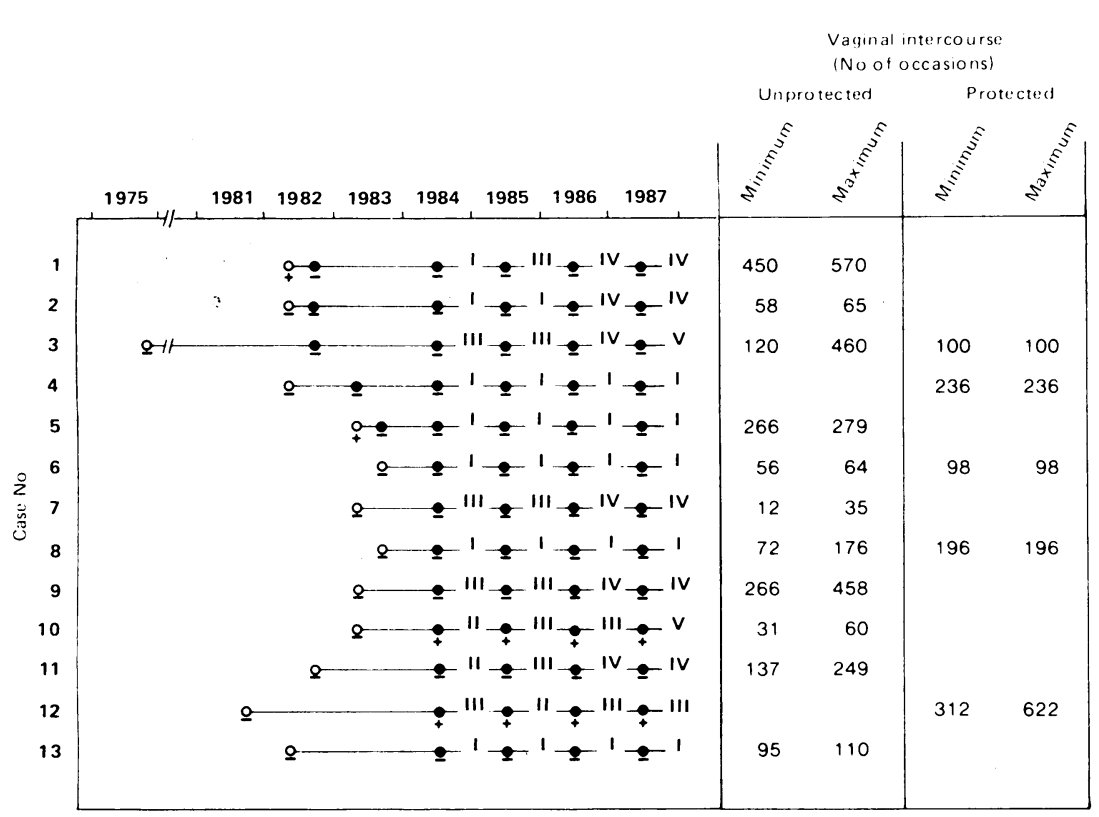

Patients' history from date of last serum sample that was negative for $H I V$ antibody $(\bigcirc)$ and estimated total number of times that patients subsequently had unprotected or protected vaginal intercourse.

$=$ Serum sample positive for HIV antibody. + = Sample positive for HIV antigen. - = Sample negative for $H I V$ antigen. $I-V=W$ Walter Reed classification of disease (see text for details) positive for HIV antibody, and four patients (cases 3, $4,6,8)$ started to use condoms after being told that they were positive. At the time of the last negative sample 12 of the patients were sexually active with their present partner. We calculated that in 11 couples unprotected vaginal intercourse occurred a maximum of 2520 times (minimum 1563) without transmission of HIV; for protected vaginal intercourse the figures were 1252 and 942 respectively (figure).

According to the Walter Reed classification, seven patients had progressive disease. Six patients (cases 3, $5,9-12$ ) developed thrombocytopenia or leucopenia, or both. Two patients had sustained antigenaemia (figure). One partner had unexplained lymphadenopathy during the three years of the study; results of serological tests for Epstein-Barr virus, cytomegalo- virus, toxoplasma, hepatitis B virus, and HIV were negative. All other partners were generally healthy, and none developed laboratory evidence of infection with HIV. None of the patients or their partners had serological evidence of active infection with cytomegalovirus or Epstein-Barr virus.

\section{Comment}

The prevalence of HIV infection in female partners of haemophiliacs positive for HIV antibody has been reported to be $6 \cdot 8-8 \cdot 0 \%$. ${ }^{34}$ The studies gave no information on risk factors, sexual habits, or disease related to HIV. Our patients had had different stages of HIV infection, including AIDS, for three to five years, and two had had continuous antigenaemia; we calculate that the rate of transmission of HIV by unprotected and protected intercourse was $<0.04-0.06 \%$ and $<0 \cdot 08-0 \cdot 1 \%$ respectively. ${ }^{\prime}$ In this calculation we assumed that the one partner with lymphadenopathy was not infected, though possibly she will become positive for HIV antibody or will develop antigenaemia during longer follow up.

We suggest that in the absence of other risk factors transmission of HIV from men to women by vaginal intercourse is infrequent.

This study was supported by the Preventie Fonds, The Netherlands. Part of it was reported at the second international conference on AIDS, Paris, June 1986.

1 May RM, Anderson RM. Transmission dynamics of HIV infection. Nature 1987;326:137-42.

2 Johnson AM. Heterosexual transmission of human immunodeficiency virus. BrMed 7 1988;296:1017-20

3 Allain JP. Prevalence of HTLV III/LAV antibodies in patients with haemophilia and their sexual partners in France. N Engl f Med 1986;315:517.

4 Jones P, Hamilton PJ, Bird G, et al. AIDS and haemophilia: morbidity and mortality in a well-defined population. Br Med $\mathcal{f}$ 1985;291:695-9.

5 Ranki A, Krohn M, Allain JP, et al. Long latency precedes overt seroconversion in sexually transmitted human-immunodeficiency-virus infection. Lancet 1987;ii:589-93.

(Accepted 29 fune 1988)

\section{Coffee and cholesterol: Is it all in the brewing? The Troms $\varnothing$ study}

\section{Kaare Bønaa, Egil Arnesen, Dag Steinar Thelle, Olav Helge Førde}

We previously reported a strong relation between consumption of coffee and serum cholesterol concentrations. ${ }^{1}$ In the third health survey in Troms $\varnothing$ we explored the possibility that the method of brewing might be important to this relation, as has been suggested. ${ }^{1-3}$

\section{Subjects, methods, and results}

During 1986-7, 21826 people in the municipality of Troms $\emptyset(81.3 \%$ of the eligible population) were screened. The present analysis is restricted to men and menstruating women aged 20-59 $(n=18012)$. We asked them how many cups of coffee and what type of coffee they usually drank each day. Total cholesterol concentration was measured by an enzymatic method with a commercial kit (cholesterol oxidase/peroxidaseamidopyrine, Boehringer Mannheim) and a Hitachi automatic analyser 737 (Boehringer Mannheim) in the division of clinical chemistry of the university teaching hospital.

Boiled coffee was the most commonly drunk brew ( $68 \%$ of both sexes). Filtered coffee was the next most popular ( $23 \%$ of the men and $20 \%$ of the women); only $2 \%$ drank instant coffee. Only $7 \%$ of the men and $9 \%$ of the women did not drink coffee at all. A small minority drank decaffeinated coffee.

The table shows the mean serum cholesterol concentrations for each sex according to consumption of coffee and method of brewing adjusted for the influence of age, body mass index, cigarette smoking, physical activity in leisure time, and salt and fat intakes. The concentration in the men who drank nine or more cups of coffee a day (all types of brew) was 0.52 $\mathrm{mmol} / \mathrm{l}(10 \%)$ higher than that in the men who did not drink coffee at all. The corresponding figure in women was $0.40 \mathrm{mmol} / \mathrm{l}(8 \%)$. For those who drank mainly boiled coffee the increase in serum cholesterol concentration between people who drank less than one and those who drank nine or more cups of coffee was 0.61 $\mathrm{mmol} / \mathrm{l}(11 \%)$ in men and $0.40 \mathrm{mmol} / \mathrm{l}$ in women. No statistical trend was observed for the other methods of brewing. There was also no correlation between consumption of coffee and serum concentrations of high density lipoprotein cholesterol and triglyceride.

\section{Comment}

Except for age coffee was the most important determinant of serum cholesterol concentration in this study. This finding confirms our previous observation that there is an association between coffee and serum cholesterol concentration in this population ${ }^{1}$ and supports the suggestion that coffee causes the concentrations to increase. 